\title{
Parathyroid Carcinoma: a Rare Cause of Hyperparathyroidism
}

\author{
Paratiroid Karsinomu: Hiperparatiroidinin Nadir Bir Nedeni \\ Atakan SEZER, Fulya ÖZ PUYAN, ${ }^{1}$ Ali SARIKAYA, ${ }^{2}$ Mehmet Emin İRFANOĞLU \\ Departments of General Surgery, ${ }^{1}$ Pathology, ${ }^{2}$ Nuclear Medicine, Medical Faculty of Trakya University, Edirne
}

Submitted/ Başvuru tarihi: 10.09.2008 Accepted / Kabul tarihi: 10.11.2008

\begin{abstract}
Parathyroid carcinoma is one of the rare causes of primary hyperparathyroidism. These tumors account for $0.4-1 \%$ of all cases of primary hyperparathyroidism and it is difficult to distinguish from benign disorders of parathyroid glands. A 61-year-old female patient previously operated for parathyroid adenoma admitted to our clinic with parathyroid carcinoma suspicion. Clinical examination revealed a mass in the right half of the thyroid gland and radiological investigation supported the diagnosis. She underwent surgery and thyroidectomy, parathyroidectomy, neck dissection and strap muscle excision were performed. The pathological investigation revealed parathyroid carcinoma. The patient was discharged uneventful with oral calcitriol and calcium replacement.
\end{abstract}

Key words: Parathyroid; carcinoma; hyperparathyroidism.
Paratiroid karsinomları primer hiperparatiroidinin nadir nedenleri arasında yer alır. Bu tümörler tüm primer hiperparatiroidilerin \%0.4-1'inde görülür ve paratiroid bezininin diğer hastalıklarından ayrımı zordur. Daha once paratiroid adenoma tanısı ile opere olan 61 yaşında bayan hasta kliniğimize paratiroid karsinomu şüphesi ile başvurdu. Hastanın klinik muayenesinde tiroid glandın sağ tarafında kitle palpe edildi ve radyolojik incelemeler tanıyı destekledi. Hastaya tiroidektomi, paratiroidektomi, boyun diseksiyonu ve strap kas eksizyonu yapıldı ve patolojik incelemede paratiroid karsinomu tanısı kondu. Hasta oral kalsiyum ve kalsitriol tedavisi ile sorunsuz olarak taburcu edildi.

Anahtar sözcükler: Paratiroid; karsinom; hiperparatiroidi.
Parathyroid carcinoma is one of the rare causes of primary hyperparathyroidism with a prevalence of $0.005 \%$ of all cancers. ${ }^{[1]}$ The overall incidence of primary hyperparathyroidism (PHP) is reported to be one in every 500 women and one in every 2000 men. The leading reason of PHP is parathyroid adenoma $(87 \%)$ and parathyroid hyperplasia (12\%). Parathyroid carcinoma accounts for $0.4-1 \%$ of all cases of primary hyperparathyroidism. ${ }^{[2-4]}$ Diagnosis of parathyroid carcinoma is difficult because malignancy is not clearly distinguishable from benign adenoma by histopathological, biochemical, and clinical features. Local tumor implants are the main manifestation type of recurrence and usually occur in $40 \%$ patients within 3 years. ${ }^{[5]}$ In suspected cases surgery offers the best chance of cure with unblock extended resection of tumor without spillage. Radiotherapy and chemotherapy are generally ineffective for these tumors. ${ }^{[1,2,5]}$ Herein we reported a successful surgical management of a parathyroid carcinoma presenting with hyperparathyroidism.

\section{CASE REPORT}

A 61-year-old female patient diagnosed as nodular goiter 22 years ago and parathyroid adenoma 5 years ago. She underwent left subtotal thyroidectomy first and parathyroidectomy at her local hospital. The patient had general weakness, lethargy, general bone 


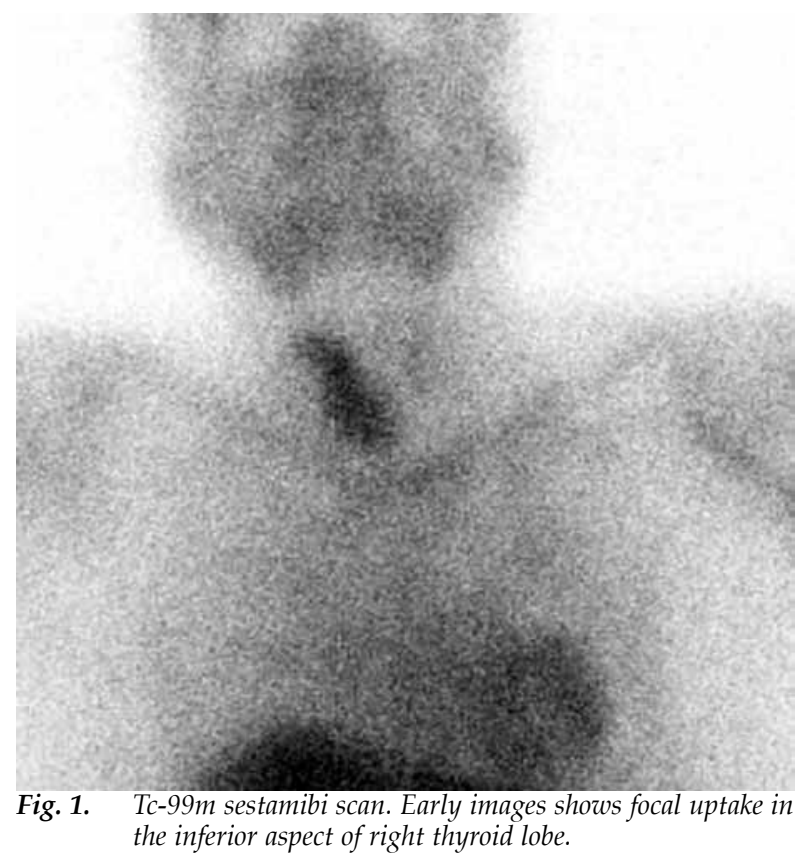

aches and multiple joints pain in her history. The histopathological examination revealed suspected malignancy of parathyroid tissue in initial surgery. She had an uneventful postoperative course with medication of hypocalcaemia. The patient admitted to our clinic with bone aches, joint pains and a mass on the right side of the neck. On clinical examination a mass was palpable in the right half of the thyroid gland. Routine laboratory investigations were with hemoglobin of $9.6 \mathrm{~g} / \mathrm{dl}$ (12.217.2), white blood cells of 7600/1 (4600-10200), blood urea nitrogen of $46 \mathrm{mg} / \mathrm{dl}$ (10-50), creatinine of $1.1 \mathrm{mg} /$ dl (0.6-1.4), glucose of $88 \mathrm{mg} / \mathrm{dl}$ (70-110), calcium 11.9 $\mathrm{mg} / \mathrm{dl}$ (8.6-10.3), phosphorous $2.5 \mathrm{mg} / \mathrm{dl}$ (2.7-4.5), albu$\min 4.1 \mathrm{~g} / \mathrm{dl}$ (3.5-5.2), parathyroid hormone (PTH) 2710 $\mathrm{ng} / \mathrm{ml}$ (12-65). The immediate post injection sestamibi scan showed focal uptake in the inferior aspect of the right thyroid lobe (Fig. 1). The 4-hours delayed image

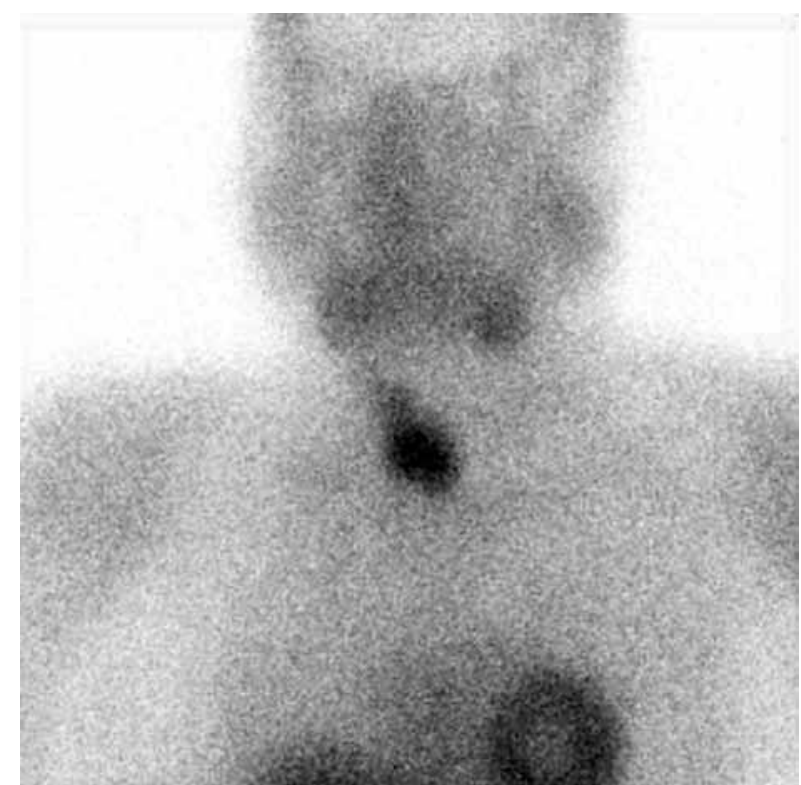

Fig. 2. Delayed scintigraphy images demonstrate washout of Tc-99m sestamibi from the thyroid gland with retention of tracer in the presumed right inferior parathyroid adenoma.

showed focal retention within a presumed right inferior parathyroid adenoma (Fig. 2). Computed tomography of the neck revealed a mass adjacent to the inferolateral of right thyroid gland (data was not shown). The patient was diagnosed as parathyroid carcinoma and referred to surgery. An apron incision was performed under general anesthesia. A cleavage between the strap muscles and skin was performed for the flap. A 3x2 cm in diameter mass originated from parathyroid adherent to strap muscles and 2 other $1.5 \times 1$ and $1.5 \times 0.7 \mathrm{~cm}$ of metastatic nodules on strap muscles were observed. The metastatic nodules, main parathyroid mass, strap muscles, thyroid lobe were unblock resected without spillage. Also right neck dissection was performed. The postoperative course was uneventful. The serum calcium levels decreased to $5.4 \mathrm{mg} / \mathrm{dl}$ and PTH to 103.8

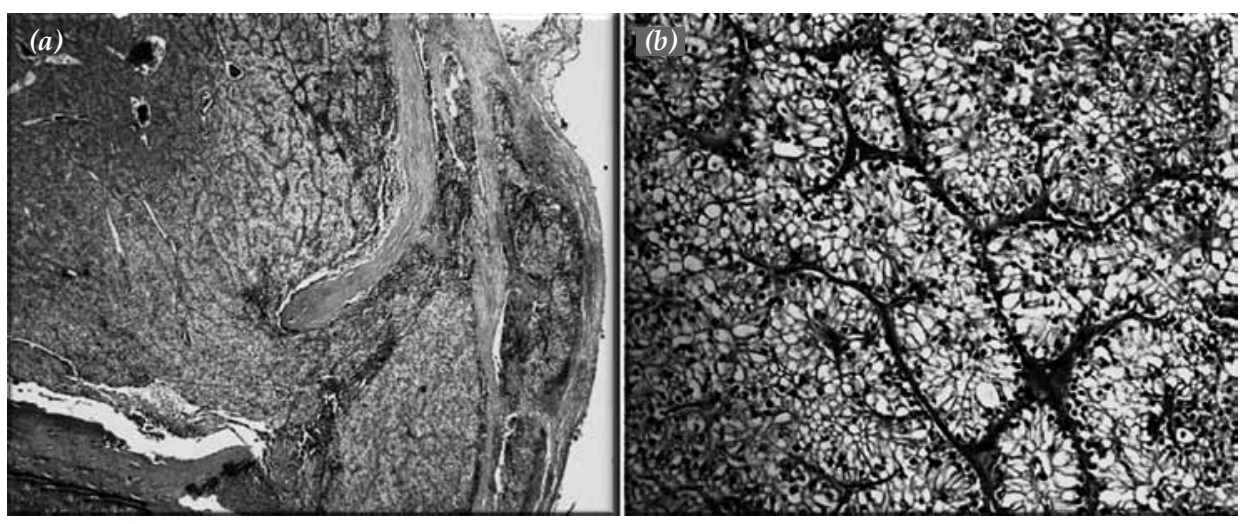

Fig. 3. (a) Parathyroid adenoma suspicious for malignancy; Sheet-like structures of neoplastic parathyroid cells within a thick capsule (HEE x 12.5), (b) High power view of the cells with clear cytoplasm (HEE $x$ 100). 


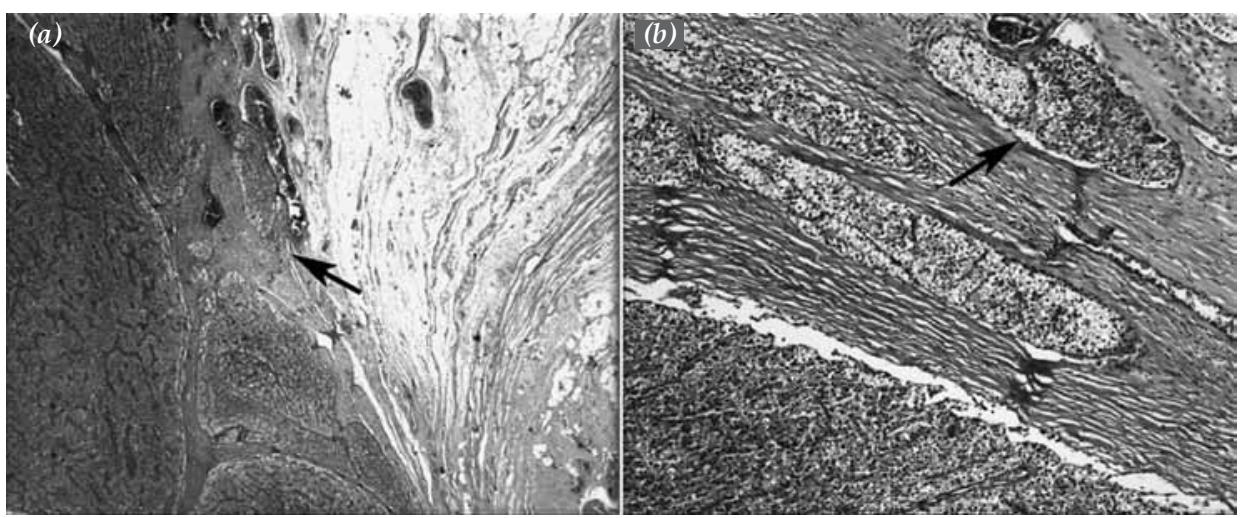

Fig. 4. (a) Parathyroid carcinoma; Neoplastic cells invaded the capsular wall (arrow) (HEE x 12.5), (b) Chief and clear carcinoma cells have invaded a vascular channel beyond the capsule (arrow) (HEE x100).

$\mathrm{ng} / \mathrm{ml}$ on the second post operative day. Intravenous calcium supplementation was started. On the 11th postoperative day the patient was discharged with oral calcitriol and calcium replacement. Parathyroid lesion from the first operation revealed a capsular lesion filled with endocrine cells in a solid and trabecular pattern. Band forming fibrosis and capsular thickening was evident on the tumoral lesion. Clear cells with bland nucleus features were arranged in a trabecular growth pattern (Fig. 3). On the second operation right lower lob of the parathyroid tissue with adjacent thyroid tissue and metastatic nodules in the strap muscles were resected. The neoplastic tumoral lesion in the parathyroid revealed same morphological features as the previous one. Distinctly there was capsular invasion with blood vessel infiltration and local metastasis (Fig. 4). Metastatic nodules were noted outside the capsular lesion beside the thyroid tissue.

\section{DISCUSSION}

Parathyroid carcinoma is a rare tumor, which is often difficult to diagnose. Approximately 700 cases of parathyroid carcinoma were reported in the English literature between 1930 and 2004..$^{[6]}$ This tumor is an uncommon reason of hyperparathyroidism which occurs less than $\% 1$ in hyperfunctioning parathyroid diseases. ${ }^{[2,3]}$ The etiology of parathyroid cancer is unknown. History of neck irradiation, prolonged secondary hyperparathyroidism due to celiac disease, or accompanying end-stage renal disease with hemodialysis, adenoma or a hyperplastic parathyroid gland are suggested predisposing factors. $[2,7,8]$ The relation between multiple endocrine neoplasia type I (MEN1) and parathyroid carcinoma is controversial but increased risk of parathyroid carcinoma associated with the hereditary hyperparathyroidism-jaw tumor syndrome is reported by Wassif et al..$^{[9]}$ and Szabo et al. ${ }^{[10]}$ The clinical manifestations of parathyroid carcinoma patients are generally depend on metabolic conditions. Most of the patients have fatigue, weakness, weight loss, anorexia, nausea, vomiting, polyuria, polydipsia, bone pain, fractures, and renal colic. ${ }^{[1,26]}$
The preoperative clinical diagnosis of the tumor is difficult. The presence of high serum calcium and PTH levels, palpable neck mass, palsy of the recurrent laryngeal nerve are suspected findings. Approximately $\% 40$ of patients with parathyroid carcinoma present with a palpable neck mass. ${ }^{[1,2,5,6]}$ This is not a frequent finding in benign parathyroid diseases. The female/male ratio is 3-4:1 in PHP but there is no association of gender with parathyroid carcinoma which is 1:1. The influence of age of the disease is 10 years earlier than PHP as fifth decade. ${ }^{[2,4]}$ In current case, the patient has a suspected parathyroid malignancy who presented with fatigue, weakness, bone aches and joint pain. She had also elevated calcium and PTH levels and a palpable mass located in the right side of neck like as in the literature. Preoperative fine-needle aspiration biopsy is contraindicated in patients with suspected parathyroid cancer because of the risk of local dissemination. These tumors are bigger than adenomas and they are macroscopically gray-white in color, hard consistency with a fibrotic capsule. Also parathyroid carcinomas have surrounding adhesions, locally invasion and spillage to the surrounding tissue. ${ }^{[2,11,12]}$ The differential diagnosis of parathyroid carcinoma from adenoma is difficult. Schantz and Castleman ${ }^{[13]}$ pointed out that a thick dense fibrous capsule and/or trabeculae that divide the tumor, sheets of cells arranged in a lobular/trabecular pattern, the presence of mitotic figures, and capsular and/or vascular invasion are the pathological criteria for the diagnosis of this malignancy. However, each feature could also be observed in a benign disease. ${ }^{[14]}$ Moreover, immunohistochemical staining, electron microscopy findings, and DNA content analysis are not helpful in the differentiation of parathyroid malignancy from benign disease. ${ }^{[2,3,14]}$ As other endocrine tumors parathyroid carcinomas are slow growing tumors. They tend to recur locally at the operative site. Common sites of locoregional invasion were the fibrofatty tissue of the neck $(80 \%)$, the strap muscles, thyroid, esophagus, and trachea $(60 \%)$, and regional lymph nodes $(40 \%)$. Distal metastasis was evident in the mediastinum (30\%), lung $(15 \%)$, bone 
$(10 \%)$, and liver (5\%). Occasional involvement of pleura, pericardium, and pancreas has been reported. The early development of metastasis was associated with a poor prognosis and death secondary to metabolic consequences of uncontrollable hypercalcaemia. ${ }^{[2,12,13,15]}$

Surgery is the most effective therapy for parathyroid carcinoma. Unblock resection of the tumor at the initial operation is critically important. When the macroscopic findings suggest malignancy the integrity of the parathyroid capsule should be maintained during dissection to avoid local seeding of the tumor. Unblock resection of lesion, thyroid lobe, isthmus and lymphatics of tracheoesophageal, and paratracheal lymph nodes should be excised. The resection of involved recurrent laryngeal nerve is mandatory. An extensive lateral neck dissection is indicated only when there is spread to the anterior cervical nodes. The management of early diagnosed tumor is debatable. If pathology appears to be aggressive with extensive vascular/capsular invasion or the serum calcium and PTH levels are still high after operation the procedures mentioned above are indicated. Otherwise complete resection of the tumor is often curative with measurements of serum PTH and calcium levels in 3 months period..$^{[1-3,5,6,11-15]}$ We performed resection of parathyroid tumor with thyroidectomy, lateral neck dissection and strap muscle resection in the current case. The patient should be monitorized for hypocalcaemia crisis after the surgical procedure. Excessive supplemental calcium and calcitriol may be necessary to maintain normocalcaemia. $30-65 \%$ of the patients will develop recurrent disease after an adequate surgical procedure. Locoregional recurrence or metastatic disease manifests itself by rising serum calcium and PTH levels. It is suggested that resection of recurrent tumor or functioning metastases should be considered both in terms of palliation and in facilitating adjunctive medical therapy. ${ }^{[1-3,12,13,15,16]}$ Physical examination of neck is the first step of detecting recurrence of tumor in hypercalcaemic patients. Thallium-201/technetium- $99 \mathrm{~m}$ scanning is useful in locating recurrent tumors in the neck and upper mediastinum. Other radiologic investigations such as computerized tomography, ultrasonography, magnetic resonance imaging are helpful in detecting distant metastasis. ${ }^{[2,17,18]}$ The response to chemotherapy and radiotherapy remains uncertain. In recurrent cases palliative radiotherapy to the neck may have a benefit in preventing tumor regrowth. Chemotherapy regimes such as adriamycin, cyclophosphamide, dacarbazine has limited effect on metastatic or recurrent disease. ${ }^{[2,13,16,19-21]}$ Metabolic manifestations of unresectable tumor leads the patients to the death and management of these conditions depend on medical treatment. The management of hypercalcaemia starts with administration of saline infusion and loop diuretics to increase calciuresis. Clodronate, etidronate, pamidronate, ibandronate, and zoledronate are other new, potent, promising drugs which lower serum calcium level in parathyroid carci- noma patients. ${ }^{[22,23]}$ The average time between surgery and recurrent is approximately 3 years. Previous reports of 5 years and 10 years survival rates are $85.5 \%$ and $49.1 \%$, respectively for patients with parathyroid carcinoma. $[2,13,15,19]$

Even though parathyroid surgery in benign diseases carries out pitfalls for experienced surgeons, carcinoma of this gland is a cul-de-sac for many physicians. The management of parathyroid carcinoma depends on a multidisciplinary approach consist of surgeon, pathologist, endocrinologist, radiologist, nuclear medicine doctor, and oncologist. Insistent high serum calcium and PTH levels and palpable neck mass after initial operation should alert this team for malignancy.

\section{REFERENCES}

1. Lee JE. Predicting the presence of parathyroid carcinoma. Ann Surg Oncol 2005;12:513-4.

2. Shane E. Clinical review 122: Parathyroid carcinoma. J Clin Endocrinol Metab 2001;86:485-93.

3. Kebebew E, Arici C, Duh QY, Clark OH. Localization and reoperation results for persistent and recurrent parathyroid carcinoma. Arch Surg 2001;136:878-85.

4. Atakan S, Ibis C, Irfanoglu ME. Hiperparatiroidizm nedeni ile ameliyat edilen hastalarımızın sonuçları. Cerrahpaşa Tıp Fakültesi Dergisi 2007;38:90-4.

5. Sandelin K, Auer G, Bondeson L, Grimelius L, Farnebo LO. Prognostic factors in parathyroid cancer: a review of 95 cases. World J Surg 1992;16:724-31.

6. Rao SR, Shaha AR, Singh B, Rinaldo A, Ferlito A. Management of cancer of the parathyroid. Acta Otolaryngol 2002;122:448-52.

7. Ireland JP, Fleming SJ, Levison DA, Cattell WR, Baker LR. Parathyroid carcinoma associated with chronic renal failure and previous radiotherapy to the neck. J Clin Pathol 1985;38:1114-8.

8. Haghighi P, Astarita RW, Wepsic HT, Wolf PL. Concurrent primary parathyroid hyperplasia and parathyroid carcinoma. Arch Pathol Lab Med 1983;107:349-50.

9. Wassif WS, Moniz CF, Friedman E, Wong S, Weber G, Nordenskjöld $M$, et al. Familial isolated hyperparathyroidism: a distinct genetic entity with an increased risk of parathyroid cancer. J Clin Endocrinol Metab 1993;77:1485-9.

10. Szabó J, Heath B, Hill VM, Jackson CE, Zarbo RJ, Mallette LE, et al. Hereditary hyperparathyroidism-jaw tumor syndrome: the endocrine tumor gene HRPT2 maps to chromosome 1q21-q31. Am J Hum Genet 1995;56:944-50.

11. Jiménez-Garcia A, Milán JA, García-Escudero A, MarínVelarde C, Cantillana J, Echenique-Elizondo M. Parathyroid carcinoma on transplanted parathyroid tissue after total parathyroidectomy for renal hyperparathyroidism. Am J Clin Oncol 2006;29:207-8.

12. Fernandez-Ranvier GG, Khanafshar E, Jensen K, Zarnegar R, Lee J, Kebebew E, et al. Parathyroid carcinoma, atypical parathyroid adenoma, or parathyromatosis? Cancer 2007;110:255-64.

13. Schantz A, Castleman B. Parathyroid carcinoma. A study of 70 cases. Cancer 1973;31:600-5.

14. Iwata $T$, Inoue $K$, Morita $R$, Mizuguchi $S$, Tsukioka $T$, Onoda N, et al. Functional large parathyroid carcinoma extending into the superior mediastinum. Ann Thorac Cardiovasc Surg 2008;14:112-5. 
15. Wang CA, Gaz RD. Natural history of parathyroid carcinoma. Diagnosis, treatment, and results. Am J Surg 1985;149:522-7.

16. McCance DR, Kenny BD, Sloan JM, Russell CF, Hadden DR. Parathyroid carcinoma: a review. J R Soc Med 1987;80:505-9.

17. Johnston LB, Carroll MJ, Britton KE, Lowe DG, Shand W, Besser GM, et al. The accuracy of parathyroid gland localization in primary hyperparathyroidism using sestamibi radionuclide imaging. J Clin Endocrinol Metab 1996;81:346-52.

18. Fujimoto Y, Obara T, Ito Y, Kodama T, Nobori M, Ebihara $\mathrm{S}$. Localization and surgical resection of metastatic parathyroid carcinoma. World J Surg 1986;10:539-47.

19. Munson ND, Foote RL, Northcutt RC, Tiegs RD, Fitzpatrick LA, Grant CS, et al. Parathyroid carcinoma: is there a role for adjuvant radiation therapy? Cancer 2003;98:2378-84.

20. Goepfert H, Smart CR, Rochlin DB. Metastatic parathyroid carcinoma and hormonal chemotherapy. Case report and response to hexestrol. Ann Surg 1966;164:917-20.

21. Bukowski RM, Sheeler L, Cunningham J, Esselstyn C. Successful combination chemotherapy for metastatic parathyroid carcinoma. Arch Intern Med 1984;144:399-400.

22. Jüngst D. Disodium clodronate effective in management of severe hypercalcaemia caused by parathyroid carcinoma. Lancet 1984;2:1043.

23. Jacobs TP, Siris ES, Bilezikian JP, Baquiran DC, Shane E, Canfield RE. Hypercalcemia of malignancy: treatment with intravenous dichloromethylene diphosphonate. Ann Intern Med 1981;94:312-6. 